\title{
EL DERECHO A LA PROPIA IMAGEN: ¿DERECHO PERSONALÍSIMO?, ¿DERECHO FUNDAMENTAL? PRECISIONES TERMINOLÓGICAS PARA EL ORDENAMIENTO JURÍDICO CHILENO
}

\author{
THE RIGHT TO ONE'S OWN IMAGE: RIGHT OF PERSONALITY? \\ FUNDAMENTAL RIGHT? TERMINOLOGICAL CLARIFICATIONS FOR \\ CHILEAN LAW
}

\section{Jorge Eduardo Aillapán Quinteros*}

\begin{abstract}
RESUMEN: A partir de la terminología usada para la construcción del derecho a la propia imagen, el autor critica el estado de la cuestión proponiendo bases para un nuevo entendimiento del retrato de personas en Chile. De esta manera, si los derechos personalísimos son extrapatrimoniales, el derecho a la imagen no pertenece a dicha categoría. Además, si bien este puede ser justificado como derecho fundamental no lo será en cuanto derecho subjetivo, sino como la "libertad de retrato".
\end{abstract}

Palabras clave: Propia imagen, retrato, patrimonialidad, derechos personalísimos, derechos fundamentales.

ABSTRACT: Based on the terminology used for the construction of the right to one's own image, the author critiques the current state of affairs by proposing the foundations for a new understanding of creating portraits in Chilean law. Thus, if the rights of personality are extra-patrimonial, the right to one's own image does not belong to that category. Moreover, while it can be justified as a fundamental right it should not be considered a subjective public right, but rather as "freedom portrait".

Key words: Own image, portrait, pecuniary rights, rights of personality, fundamental right.

\section{INTRODUCCIÓN}

La ausencia de reconocimiento explícito del "derecho a la propia imagen" en la Constitución y en el Código Civil ha llevado a nuestra doctrina y jurisprudencia a construirlo sobre la base de fuentes conocidas como el art. 19 No 4 CPR (vida privada y honra de la persona) o el art. 19 No 24 (propiedad sobre cosas incorporales), ignorando aquellas normas que mandan, prohíben y permiten retratar personas, dispersas en el mismo Código Civil, la legislación sobre Propiedad Intelectual, ley de prensa, el Código Procesal Penal, etcétera.

Abogado, Universidad de Concepción. Diplomado en Propiedad Intelectual, Universidad de Chile. Becario CONICYT y candidato a Doctor en Derecho, Pontificia Universidad Católica de Valparaíso. Dirección postal: Freire 480-C, Penco, VIII región, Chile. Correo electrónico: abogado@aillapan.cl 
Por otra parte, en el análisis de estos conflictos se olvida que la sola creación de un retrato genera ya derechos de autor en favor del retratista ${ }^{1}$, es decir, no se atiende al hecho que propiedad intelectual y derecho a la imagen son "dos caras de un mismo fenómeno"2: la libertad de retrato ${ }^{3}$.

Otro error que ha influido decididamente en la actual concepción de aquel es la taxonomía y terminología utilizada para su tratamiento: los "derechos de la persona". En efecto, desde la segunda mitad del s. XX que los civilistas vienen designándolo como un "derecho personalísimo" carente de patrimonialidad y traficabilidad, en abierta contradicción con el Derecho positivo chileno que, al menos, desde la promulgación del Código Civil en 1857, permite a toda persona autorretratarse, adquirir créditos para que un tercero la retrate e, incluso, obligarse para con otros a dejarse retratar, habitualmente, a cambio de dinero como ocurre con el contrato innominado de "cesión de derechos de imagen". Por otra parte, desde esa misma época que la categoría derechos de la persona ha sido confundida con los "derechos humanos" y los "derechos fundamentales". De ahí que, para referirse al derecho a la imagen, la literatura jurídica hable, indistintamente, de derecho "personalísimo", "humano" y/o "fundamental", sin que se ofrezcan precisiones conceptuales en la nomenclatura utilizada.

El presente trabajo busca pasar revista a la terminología y taxonomía utilizada para referirse al derecho a la imagen en Chile y, a partir de ello, proponer las bases para una adecuada reconstrucción del fenómeno del retrato de personas en nuestro país.

\section{APROXIMACIÓN AL CONCEPTO DE IMAGEN}

En el ordenamiento jurídico chileno, la palabra "imagen” es usada con diferentes significados. En una somera revisión, encontramos normas donde imagen hace referencia a un objeto corporal ${ }^{4}$ como, también, a la reputación o "imagen” institucional". Es más, existe una Fundación llamada "Imagen de Chile", de composición público-privada, cuyo eje principal de trabajo es "estudiar y comprender en toda su complejidad la imagen que

\footnotetext{
1 Consecuencia del "principio de protección automática" recogido en el art. 1 inc. I de la ley 17.336 de 1970: "La presente ley protege los derechos que, por el solo hecho de la creación de la obra, adquieren los autores (...)".

2 Cifuentes (1995) p. 522.

3 En adelante, usaremos nuestro neologismo "libertad de retrato" como sinónimo de "derecho a la propia imagen".

4 Así, el Decreto N 1976 exento de 2007 que declaró Monumento Nacional al "Santuario Inmaculada Concepción de Corinto", ubicado en la VII Región, señala en sus considerandos: "Que, la importancia de esta imagen radica en dos aspectos, el primero es que es de las pocas imágenes auténticas que quedan de la Virgen con el vientre abultado, dado que esto fue prohibido en el Concilio de Trento (1545-1563) y se les retiró el vientre a casi todas las imágenes, quedando solo unas pocas".

5 Así reza el enunciado del art. 10 de la LEY No 20.564 de 2012 cuando señala: "En caso de suceder un conflicto o situación que afecte la seguridad de la población, sea que haga peligrar la continuidad o la administración del servicio bomberil, implique la paralización de este o comprometa la imagen de los Cuerpos de Bomberos frente a la ciudadanía (...)".
} 
nuestro país proyecta en el exterior, captando de paso los diferentes matices que la caracterizan en los distintos ámbitos en que ella juega un papel relevante" ${ }^{16}$.

Esta diversidad de significados atribuidos al vocablo imagen por parte de nuestro legislador, la encontramos, también, en la más autorizada doctrina chilena, tal como da cuenta el siguiente pasaje de un artículo de Humberto Nogueira: "En casos de eventuales tensiones entre el ejercicio del derecho a la propia imagen y el ejercicio de determinados roles dentro de establecimientos educacionales, empresas u otros, corresponderá a los tribunales de justicia, determinar analizando las circunstancias de cada caso concreto./ En tal caso es necesario preguntarse si el individuo está relacionándose por sí mismo con las demás personas y la comunidad, o si representa la imagen de una institución, la que está determinada en sus respectivos estatutos jurídicos. Si estamos en el segundo caso, consideramos que la imagen debe ajustarse a los cánones e imagen corporativos. Por el contrario, si solo está en juego la individualidad del sujeto, en la medida que toma contacto con los demás desde su propia individualidad, puede elegir las opciones estéticas que considere conveniente, por lo cual la imposición de un determinado estereotipo sería un atentado al derecho a su propia imagen./ El derecho a la apariencia en la actividad laboral debe conjugarse con la libertad de empresa y la actividad productiva (...) no basta que una orden sea legítima prima facie, sino que es necesario acreditar que la restricción del derecho a la imagen del trabajador sea instrumental al efectivo desarrollo de su trabajo explicitado en su contrato de trabajo" 7 . Y pese a reivindicar la existencia de una "imagen corporativa" o empresarial, el mismo Nogueira agregará que: "el derecho a la propia imagen es propio de los seres humanos y no de personas jurídicas, las cuales pueden tener una imagen comercial pero no un derecho de la personalidad que es propio únicamente de las personas

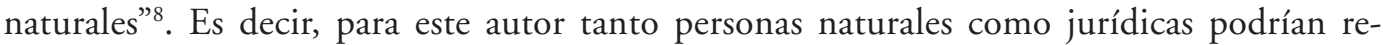
clamar protección a su imagen. Nosotros, en cambio, pensamos que ello solo favorece la confusión en la terminología y los conceptos a usar en el tratamiento del tópico.

Desde una perspectiva ontológica, cuando se discute sobre nuestra imagen se descar$\tan$ a priori las "imágenes mentales", propias de la Neurología o de la Filosofía". Y es que el derecho a la imagen dice relación con la Óptica, esto es, aquella parte de las ciencias físicas dedicada a estudiar el fenómeno de la luz. Por eso que, en una primera aproximación, nos guíe uno de los tantos significados que la Real Academia de la Lengua Española (RAE) entrega para imagen: "[r]eproducción de la figura de un objeto por la combinación de los rayos de luz que proceden de él”10. Explicando, aún más, el fenómeno que nos interesa, podemos esbozar el siguiente esquema que descubre el hecho jurídico que constituye la base de estudio del denominado derecho a la imagen:

i) hipótesis no 1: si solo existe un ente (objeto o persona) y presencia de luz, estaremos frente a un mero hecho de la naturaleza;

\footnotetext{
6 Así se lee en la presentación de su página web http://www.imagendechile.cl/quienes-somos/presentacion/. Fecha de consulta: 27 de marzo de 2015.

7 Nogueira (2007) p. 271.

8 Nogueira (2007) p. 275.

9 Como en la "Teoría de la ideas" de Platón.

10 Disponible en: http://lema.rae.es/drae/?val=imagen. Fecha de consulta: 27 de marzo de 2015.
} 
ii) hipótesis $n^{\circ} 2$ : si además del ente (objeto o persona) y la presencia de luz, existe un sistema óptico y/o una superficie apta para reflejar los rayos luminosos que inciden sobre el ente corresponderá, también, a un hecho de la naturaleza: generación de una imagen real o virtual ${ }^{11}$;

iii) hipótesis no 3: si concurriendo el ente (objeto o persona), la presencia de luz, el sistema óptico y/o superficie apta para reflejar los rayos luminosos que inciden sobre aquel, existe, además, un acto mimético tendiente a reproducir la imagen de aquel, estaremos recién en presencia del fenómeno que resulta relevante para el Derecho, cual es la captación o fijación de estas ${ }^{12}$.

Aplicada esta última hipótesis al ordenamiento jurídico chileno, podemos comprobar que la libertad general de las personas para captar imágenes está sujeta a dos límites principales. El primero se refiere a la regulación para captar imágenes de objetos y, en general, entes que no sean personas. Ejemplo de ello son los arts. $71 \mathrm{~F}$ de la ley 17.336 (que autoriza la reproducción de obras de arquitectura por medio de imágenes), el inc. I del art. 161-A del Código Penal (que prohíbe captar imágenes de documentos privados), o el art. 21 No 11 del D.S. No 910 del Ministerio de Obras Públicas (que prohíbe captar imágenes en el Metro) ${ }^{13}$.

El otro límite a la libertad general para captar imágenes se refiere a los seres humanos y dice relación con aquellas normas que regulan, básicamente, la creación de retratos y que, clásicamente, se ha dado en llamar "derecho a la propia imagen"14.

11 Sin perjuicio de la presencia (actual o remota) de un espectador, en cuyo caso podría transformarse en un hecho jurídico, aunque relacionado con el derecho a la vida privada y no con la imagen de la persona. Es lo que ocurriría, verbigracia, si un tercero espía a través de binoculares o una cámara de video vigilancia.

12 No solo la fijación resulta importante para el Derecho. También lo es la reproducción, publicación y comunicación pública de imágenes, aunque a ello concurrirán otros estatutos normativos como el de la libertad de expresión, la presunción de inocencia, etcétera.

13 La discusión sobre esta norma alcanzó notoriedad a propósito de un joven que captó fotografías en el Metro de Santiago y fue multado por ello. Esta noticia está disponible en: http://www.adnradio.cl/noticias/nacional/ joven-fue-multado-por-tomar-foto-durante-la-hora-punta-en-el-metro-de-santiago/20150812/nota/2890383. aspx. Fecha de consulta: 28 de agosto de 2015. Cabe destacar que dicha discusión se enmarca dentro de la cuestión conocida en el Derecho comparado como Panoramafreiheit o "Libertad de Panorama", Newell (2011) pp. 405-428.

14 Nosotros optamos por hablar de "libertad de retrato" (y no derecho a la imagen) ya que si atendemos al ordenamiento jurídico chileno identificaremos una serie de normas permisivas, imperativas y prohibitivas que (aunque dispersas) dicen relación con la captación, uso y abuso de imágenes, en general, y sobre retratos personales, en particular, cuya sistematización permitiría construir un estatuto, de aplicación universal, para dar respuesta al fenómeno del retrato de personas. Sin ir más lejos, normas imperativas son las destinadas a favorecer la identificación personal mediante fotografías incluidas en la cédula de identidad, el pasaporte y en el prontuario penal, lo cual fluye de los arts. 1 y 2 de la resolución $N^{\circ} 861$ exenta de 2013 (que señala las características de la cédula de identidad electrónica que emita el Registro Civil) y, asimismo, del art. 1 del D.S. $\mathrm{N}^{\circ} 64$ de 1960 (que reglamenta la eliminación de prontuarios penales, de anotaciones y el otorgamiento de certificados de antecedentes). Ejemplos de normas prohibitivas son el art. 33 inc. II de la ley 19.733 de 2001, en cuanto prohíbe la divulgación, por cualquier medio de comunicación social, de la identidad (o de cualquier otro antecedente que conduzca a ella) de las víctimas de determinados delitos. También, en el Código Procesal Penal existen normas prohibitivas como el inc. final del art. 289 que faculta al tribunal para prohibir los retratos en las audiencias. 


\section{DIFERENCIAS CONCEPTUALES ENTRE IMAGEN Y RETRATO}

Hablar de derecho "a la imagen" o "a la propia imagen” no es más que una metonimia. Evidentemente, la actividad regulada por el Derecho dice relación con la generación de retratos (cosa corporal) y no de meras imágenes ópticas pues estas se producen espontáneamente y aun contra nuestra voluntad, como cuando miramos a otra persona o nos vemos reflejados en un charco. Pero aun así, el objeto de este derecho no es "al propio retrato". Desde luego pues, si de reivindicar se trata, cuando se ejerce el derecho a la imagen no se pretende una cosa corporal. Es más, debemos considerar que todo retrato es una obra protegida por Derecho de autor que integra el patrimonio del retratista ${ }^{15}$, de modo que toda disputa al respecto deja de ser solo una cuestión de derecho a la imagen y pasa a ser, también, una cuestión sobre Propiedad Intelectual ${ }^{16}$. Para explicar esto podemos acudir a la nomenclatura técnica utilizada en este último ámbito y afirmar que cuando se habla del derecho "a la imagen", efectivamente, se utiliza una metonimia pues el corpus mechanicum viene a reemplazar al corpus misticum, donde el primero correspondería al resultado (el retrato) y el corpus misticum al sustrato (la efigie humana cuya reproducción regula el Derecho $)^{17}$. Mejor, entonces, sería hablar del "derecho a autorretratarnos y determinar cuándo, dónde y quién puede retratarnos" o bien del "derecho a la autodeterminación respecto a los retratos", aunque más preciso resulta decir "libertad de retrato". Creemos que es más adecuada esta última nomenclatura pues la palabra retrato da cabida a una serie de obras resultantes de la actividad de retratar y no solo a las fotografías o videos. El verbo retratar es definido por la RAE como: "[1.] Copiar, dibujar o fotografiar la figura de una persona o de una cosa; 2. Hacer la descripción de la figura o del carácter de una persona; 3. Imitar (II asemejarse); 4. Describir con exacta fidelidad algo; 5. Retractar"18. Congruentemente, la misma RAE define retrato como: "[1]. Pintura o efigie principalmente de una persona; 2. Descripción de la figura o carácter, o sea, de las cualidades físicas o morales de una persona; 3. Aquello que se asemeja mucho a una persona o cosa; 4. Retracto" ${ }^{19}$. Así, "retrato" no solo es sinónimo de la copia fiel de la efigie humana reproducida en una escultura, fotografía, dibujo o video. También abarca evocaciones y hasta las imitaciones o personificaciones realizadas por otros ${ }^{20}$.

\footnotetext{
15 Garantizado por el art. 19 No 25 CPR en relación al art. 19 No 24 CPR, en lo que resulte pertinente.

16 De donde surgen importantes conflictos de constitucionalidad como la expropiación del Derecho de autor cada vez que una Corte de Apelaciones o la Corte Suprema, conociendo recursos de protección, ordenan la destrucción de las imágenes infractoras. Así ocurrió, por ejemplo, en el comentado caso BOHME CON CLÍNICA ALEMANA (1992).

17 En el ámbito del Derecho de autor, se habla de corpus misticum para referir a la obra protegida por esta legislación especial y de corpus mechanicum a la forma sensible en que se expresa. Así, en el caso de la fotografía, la obra o corpus misticum corresponde a la composición, es decir, el motivo, el encuadre, el ángulo preciso, la luz, etcétera; el corpus mechanicum, en cambio, sería el resultado: la "imagen fija producida sobre una superficie sensible a la luz o a otra radiación, cualquiera que sea la naturaleza técnica del procedimiento -químico, electrónico, etcétera-", LiPSZYC (1993) p. 83, es decir, el retrato.

18 Disponible en: http://buscon.rae.es/drae/srv/searh?val=retrata. Fecha de consulta: 12 de agosto de 2015.

19 Disponible en: http://lema.rae.es/drae/?val=retrato. Fecha de consulta: 12 de agosto de 2015.

20 Sobre los imitadores y “dobles" Igartua (1991) pp. 48 y ss.
} 
Entre imagen y retrato hay una relación de género a especie. El retrato se distingue por dos cualidades: i) es una imagen que reproduce la efigie de un ser humano, y ii) permite su identificación o aporta datos suficientes para ello. En otras palabras, si determinada imagen no permite identificar a una persona en concreto no constituirá un retrato, ergo, no se verá afectado el derecho a la imagen de esta ${ }^{21}$.

Terminológicamente, la palabra retrato ${ }^{22}$ es más pertinente en aras de una adecuada reconstrucción del derecho a la imagen desde que especifica el tipo de obra que se busca crear o traficar, según los casos. Además, está en plena concordancia con la norma chilena más antigua referida al tópico ${ }^{23} \mathrm{y}$, también, con la literatura comparada donde ya existen antecedentes del uso de este vocablo ${ }^{24}$.

\section{LA “PROPIEDAD” SOBRE NUESTRA IMAGEN}

Para referirse a nuestro objeto de estudio se utilizan, indistintamente, las frases derecho a la "imagen" y derecho a la "propia imagen”, mas ¿tiene alguna trascendencia el adjetivo propia? Pareciera que se trata de un pleonasmo, misma crítica que se ha formulado para la expresión derechos humanos ${ }^{25}$. En Chile, se ha justificado la utilización de este adjetivo pues haría referencia inmediata a la representación sensible de la figura humana ${ }^{26}$. No obstante, la problemática surge por su vinculación con el fenómeno de la "propietarización de los derechos" ${ }^{27}$. En efecto, durante la vigencia de nuestra actual Constitución, las Cortes de Apelaciones y la Corte Suprema han declarado, en reiteradas oportunidades, que una de las fuentes del derecho a la imagen es el art. 19 No 24 CPR. El principal argumento esbozado es que al ser la imagen una "cosa incorporal" somos dueños de ella, encontrando protección constitucional en la citada norma que ampara "el derecho de propiedad en sus diversas especies sobre toda clase de bienes corporales o incorporales". Y salvo alguna

\footnotetext{
21 Por ejemplo, la C.A. de Santiago en COHEN CON LA TERCERA (2000) rechazó un recurso de protección interpuesto, precisamente, pues la imagen no permitía identificar al recurrente. En el considerando cuarto se lee: "[q]ue ha de requerirse necesariamente como exigencia fáctica básica que la figura utilizada sea reconocible, es decir, permita su identificación indubitada, situación que no se verifica en la fotografía publicada dada las características de la toma a que se ha hecho mención en el motivo tercero, siendo imposible para estos jueces concluir a partir de los antecedentes analizados que alguna de las figuras que aparecen en la fotografía tantas veces mencionada, corresponde a la persona del recurrente $(. .$.$) razón por la que el presente recurso no ha de$ prosperar".

22 Retrato, en portugués; ritratto, en italiano; portrait, en inglés y francés; porträt, en alemán; etcétera.

23 Actualmente, el art. 20 letra c) de la ley 19.039 prohíbe registrar como marca comercial "el retrato de una persona natural cualquiera (...)”. Desde principios del s. XX dicha norma solo ha sufrido mínimas alteraciones. En efecto, el D.L. No 588 de 1925 decía en la primera parte de su art. 24 letra c): “[N]o pueden rejistrarse como marcas: el nombre, el pseudónimo, el retrato o la firma de una persona cualquiera, salvo el caso de consentimiento espreso dado por ella o por sus herederos si hubiere fallecido (...)".

24 Vercellone, Paolo (1959): Il diritto sul proprio ritratto (Torino, Utet).

25 García-Huidobro (1998) p. 13.

26 Y no a la imagen como sinónimo de reputación, Peña (2001) p. 281.

27 Sobre la "propietarización", Vergara (1992) pp. 281-291; DOMÍngueZ (1996) pp. 127 y ss; GuZMÁN (2006) pp. $101 \mathrm{yss}$.
} 
reticencia inicial ${ }^{28}$, nuestra jurisprudencia continúa fallando con recurso a dicha tesis, sustentada, también, por autores chilenos como Corral para quien en estos casos (y ante la insuficiencia de las acciones ordinarias) "siempre queda abierto el camino para acudir a la protección de la Constitución mediante la vía indirecta del derecho de propiedad sobre bienes incorporales" 29 .

La idea de un derecho de propiedad sobre nuestra imagen, necesariamente ha de abandonarse. Desde luego, pues no se trata de una cosa corporal sobre la cual reclamar un derecho real. Y si bien en ejercicio de nuestra libertad podemos crear derechos personales no por ello han de confundirse con el objeto de la misma, de ahí que tampoco pueda reclamarse un cuasi dominio sobre nuestra imagen, en cuanto cosa incorporal. Pese a las conexiones, tampoco se trata de una producción del talento o del ingenio sobre la cual exista, también, una especie de propiedad ${ }^{30}$. Siguiendo a Guzmán, solo es posible hablar de propia (imagen) como cualidad genérica de lo propio, mas nunca para calificar como derecho de propiedad la relación jurídica que existe entre la persona y el objeto (conducta, comportamiento) regulado por el ordenamiento jurídico, de ahí que la tesis que plantea que sobre nuestra imagen existe tal derecho real, quede absolutamente descartada en Chile ${ }^{31}$.

\section{SOBRE EL OBJETO DEL DERECHO A LA IMAGEN}

Cuando se habla de la protección de nuestra imagen no se busca impedir que la luz incida sobre nosotros, volviéndonos invisibles. Técnicamente, lo que se busca a través de esta prerrogativa es evitar que esa reflexión luminosa pueda ser capturada o fijada por cualquier método que posibilite la generación de un retrato de ahí que, en una primera aproximación, podamos decir que el objeto de aquella consista en regular el consentimiento para "copiar, dibujar o fotografiar la figura de una persona" ${ }^{32}$. Aunque, cabe destacar, no se reduce solo a ello, pues debe añadirse la posibilidad de autorretratarse y, además, la facultad para comerciar "derechos de imagen".

Décadas atrás, Novoa describía la cuestión señalando que, para un sector, "todo lo que es susceptible de ser contemplado por cualquiera, con los medios naturales de visión, en los lugares públicos, podría quedar fijado en una placa fotográfica, sin que pudiera advertirse en ello cambio sustancial alguno, salvo el accidente de la inmovilidad de la reproducción -si se trata de mera fotografía- o de la durabilidad de ella. Conforme a este

28 Como en el comentado fallo CASZELY CON SALO EDITORES (1982), donde la C.A. de Santiago señaló en su cons. 43 que "(...) el uso hecho por terceros - con fines de lucro por cierto- de sus fotografías no vulnera su integridad moral ni si intimidad; tampoco un posible derecho de propiedad sobre sus imágenes”, sentencia citada en Anguita (2006) p. 382.

29 Corral (2006) p. 260. Recientemente, por ejemplo, la C.A. de Valparaíso en ALVARADO CON CANAL 13 (2014) dispuso en su considerando octavo que: "la imagen corporal es un atributo de la persona y como tal, corresponde a cada individuo autorizar su uso, constituyendo un derecho incorporal protegido por la Constitución Política de la República en el artículo 19 N²4".

30 Nuestra imagen no es una "obra” o una "creación” para efectos de la legislación autoral.

31 GuZMÁn (2006) pp. 136 y ss.

32 Primer significado que la RAE entrega para el verbo "retratar". Disponible en: http://lema.rae.es/ drae/?val=reflexi\%C3\%B3n. Fecha de consulta: 4 abril de 2015 . 
criterio cualquiera podría fotografiar en las calles a todo el que se encuentra en ellas, si con ello no afecta ni su honor ni su vida privada (...)"33, criterio que ha prevalecido en Chile ${ }^{34}$. Según este mismo autor, hasta mediados del s. XIX "el derecho a la imagen apenas si podía originar conflictos jurídicos. Como no podía obtenerse el retrato físico de una persona sino a condición de que ella aceptara posar para el artista, era raro encontrar casos en que alguien reclamara del mal empleo de su imagen; y cuando ello ocurría, el problema podía ser resuelto sin graves dificultades, analizando o interpretando el convenio que había mediado entre el retratado y el artista conforme a los correspondientes cánones de derecho privado" 35 . En efecto, fue el desarrollo tecnológico lo que motivó a la ciencia jurídica a prestar atención a este subestimado fenómeno de retratar personas ${ }^{36}$ que, como ha dicho Ferrara, abarca desde "la afectividad familiar a las necesidades del arte, de la glorificación de los hombres eminentes a la exacerbación pública de los grandes delincuentes, de la curiosidad del público al humorismo de las caricaturas, de la exaltación social o privada del efigiado a la necesidad de la identificación fotográfica de los individuos por razones de expedición de documentos de identidad, de policía o de seguridad pública" ${ }^{37}$.

En Chile, la explicación del derecho a la imagen ha resultado una empresa poco exitosa. Lamentablemente, no hay norma expresa en el Código Civil que lo reconozca ${ }^{38}$; tampoco forma parte del catálogo de derechos constitucionales. Y aunque, en años recientes, se ha promulgado legislación especial esta solo se refiere a personas que ejercen determinadas y precisas actividades ${ }^{39}$, de ahí que se dude no solo de la construcción dogmático-jurisprudencial, sino hasta de la existencia misma de aquel ${ }^{40}$.

Es en este contexto, que el estudio del tópico cobra importancia en Chile. Por una parte, pues se ha transitado desde su consideración ius privatista como derecho de la personalidad (y extrapatrimonial) hasta lograr reconocimiento jurisprudencial en cuanto derecho fundamental implícito y autónomo, pese a que en su fundamentación y estructura no haya conseguido independizarse, aún, del derecho a la vida privada consagrado en el art. $19 \mathrm{~N}^{\circ}$ $4 \mathrm{CPR}^{41}$. Incluso, resuelta la cuestión de su constitucionalidad, restará armonizar dicha concepción con su reconocimiento infraconstitucional expreso y la jurisprudencia que se

\footnotetext{
33 Novoa (1981) pp. 68-69.

34 En efecto, la tesis principal en Chile dice que el derecho a la imagen es un aspecto más de la privacidad de la persona, ViaL (2000) p. 58.

35 Novoa (1981) p. 64.

36 Recién a principios del s. XIX se inauguró, en Europa, una incipiente legislación ad hoc como las leyes alemanas de noviembre de 1842 y de enero de 1876, la normativa sobre Propiedad Intelectual y artística de Austria de 1885 y la ley belga sobre el Derecho de autor de 22 de marzo de 1886, Azurmendi (1998) pp. 51 y ss.

37 Citado por Royo (1987) p. 19.

38 Sin perjuicio, de aquellas normas como el art. 1466 CC. o los arts. 2006 y ss. del CC. de las cuales nos servimos para proponer la tesis sobre la libertad innominada de retrato.

39 El Código del Trabajo regula solo la situación de artistas y deportistas sujetos a contrato de trabajo en los arts. 145-I y 152 bis F.

40 LYON (2007) p. 163.

41 Y aunque así fuera, señala Vial, la delimitación entre vida privada e imagen crearía a su vez el problema de justificar a este como derecho constitucional, Vial (2000) p. 58. En este sentido, Carlos Peña ha señalado que, aun incluyendo a los Tratados Internacionales, el problema subsiste, Peña (1996) p. 598.
} 
está generando, pues de asumir que se trata de un derecho fundamental implícito estaríamos frente a pronunciamientos por parte de jurisdicciones que no están concebidas para el manejo de categorías propias del derecho constitucional, arriesgando la denunciada "expansión y vaciamiento del contenido fundamental de los derechos" ${ }^{2}$.

\section{LA INCARDINACIÓN DEL DERECHO A LA IMAGEN EN LA CATEGORÍA "DERECHOS DE LA PERSONA"}

La expresión derechos de la persona resulta polisémica ${ }^{43}$, de ahí que nuestra dogmática denuncie la dificultad para abordar el estudio de esta categoría pues se entrecruzan aspectos de Derecho civil, constitucional e, incluso, comercial ${ }^{44}$.

Desde el ámbito constitucional, la incardinación en este del derecho a la imagen se muestra cotidiana y evidente, siendo su corolario el estatus de derecho fundamental asignado por la doctrina y jurisprudencia chilenas ${ }^{45}$. No obstante, esta asunción plantea diversos problemas que dificultan su comprensión y obligan a su análisis. En primer término, la transposición desde el Derecho civil al horizonte constitucional parece haberse realizado de manera irreflexiva, sin consideración a las características de los derechos de la personalidad ni, mucho menos, a la naturaleza sui generis mostrada por el derecho a la imagen, particularmente, sus cualidades de patrimonialidad y traficabilidad. En segundo lugar, siendo los derechos fundamentales un concepto típico del Derecho constitucional surge el desafío de justificar como tal a nuestro objeto de estudio ya que la Carta Magna de 1980 nada (explícito) dice respecto a él, obligando al intérprete a fundamentar dicho estatus ${ }^{46}$. Por último, si concluimos que el derecho a la imagen es un derecho fundamental, habrá que atender a la apertura del sistema de fuentes constitucionales, más aún considerando las serias dificultades interpretativas que los retratos no autorizados están generando en ámbitos cruciales como la aportación de prueba en el proceso penal ${ }^{47}$.

Se dice que el origen filosófico de los conceptos de igualdad y dignidad humana data

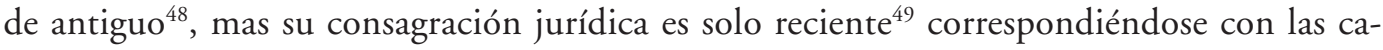
tegorías de los derechos de la personalidad, derechos humanos y derechos fundamentales,

42 Aldunate (2008) p. 105.

43 GuZMán (1988) p. 105.

44 Larraín (2012) p. 576; Cea (1982) p. 197; López (1982) p. 76; Peña, 1996, pp. 565-566; Vial (2000) p. 52.

45 Por todos Nogueira (2007).

46 Especialmente, su trascendencia política.

47 Oliver Calderón, Guillermo (2006): “¿Autorización judicial para fotografías o filmaciones en lugares públicos? A propósito de un fallo acerca del alcance del art. 226 del Código Procesal Penal”, Revista de Derecho de la Pontificia Universidad Católica de Valparaíso, No 27: pp. 149-154.

48 GuZmán (2001) pp. 138-139. Aldunate (2008) p. 8.

49 En Chile, la Constitución de 1828, en su art. 11, fue la primera en declarar abolida la esclavitud: "En Chile no hay esclavos; si alguno pisase el territorio de la República, recobra por este hecho su libertad”. Según GarcíaHuidobro "[d]iversos autores han puesto de relieve que la teoría de los derechos naturales o del hombre solo no es central, sino que incluso desconocida en el pensamiento pre-moderno", García-Huidobro (1998) pp. 1516; Aldunate (2008) pp. 9 y 15. 
conceptos (aparentemente) intercambiables. De ahí que, opinando sobre el derecho a la propia imagen, no sea extraño encontrar en nuestra literatura redacciones del tipo: "dentro de los derechos de la personalidad -o fundamentales-, que se suelen denominar como derechos del 'patrimonio moral' del individuo, se encuentra el derecho a la propia imagen" 50 . Misma crítica vale para nuestra jurisprudencia. En efecto, la Corte Suprema ha llegado a calificar al derecho a la imagen, en una misma sentencia, como derecho de la personalidad, atributo de la personalidad y derecho esencial que emana de la naturaleza humana ${ }^{51}$, sin hacer distingos conceptuales al respecto.

No obstante, desde mediados del s. XX que nuestra doctrina ha intentado perfilar dichos conceptos en atención a sus orígenes históricos, su estructura normativa, los sujetos que participan de la relación jurídica e, incluso, por sus propias finalidades. Se ha dicho que los derechos de la personalidad (o personalísimos ${ }^{52}$ ) poseen ribetes más bien civiles, como el derecho al nombre o a la imagen ${ }^{53}$. Estos han sido reclamados por el Derecho civil como una de sus construcciones decimonónicas más importantes ${ }^{54}$. Decía Fueyo que solo cuestiones políticas (posteriores a la Revolución Francesa) lograron arrebatar a la iusprivatística el tratamiento de los derechos de la personalidad, aunque nada impediría que estos volvieran a su lugar de origen, situación de suma urgencia teniendo en cuenta la latitud con que son abordados por el Derecho constitucional ${ }^{55}$. Respecto al derecho a la vida privada, por ejemplo, se ha dicho que su resguardo no formó parte del catálogo de ninguna de las Constituciones o Declaraciones del s. XIX, y que fue el Derecho común el que, en definitiva, determinó los mecanismos de protección aplicables, testimonio de la insuficiencia del Derecho público para hacer frente a este tipo de cuestiones ${ }^{56}$.

El argentino Santos Cifuentes (de evidente influencia en nuestro medio) define los derechos personalísimos como aquellos "derechos subjetivos privados, innatos y vitalicios que tienen por objeto manifestaciones interiores de la persona y que, por ser inherentes, extrapatrimoniales y necesarios, no pueden transmitirse ni disponerse en forma absoluta y radical" ${ }^{57}$. Tradicionalmente, se han mencionado como tales el derecho a la vida, al honor, a la privacidad y, también, el derecho a la imagen. Al mismo tiempo, la dogmática y juris-

50 Larraín (2012) p. 573. En el mismo sentido, Cea (1996) pp. 27-28; Pfeffer (2000) p. 465.

51 Considerando sexto de la sentencia de la Corte Suprema en causa CRUZ CON CONSEJO DE DEFENSA DEL ESTADO (2010).

52 Sobre la justificación de la expresión “derechos personalísimos”, Cifuentes (1995) p. 196.

53 GuZMán (2006) p. 55.

54 Rogel (2007) pp. 269-270 y 274.

55 Fueyo (1990) pp. 19-21; Cifuentes (1995) pp. 114-116, 118 y 223; Figueroa (2001) p. 59.

56 SuÁrez (2000) p. 105.

57 Cifuentes (1995) p. 200. 
prudencia chilenas definen a los derechos personalísimos como originarios ${ }^{58}$, universales ${ }^{59}$, subjetivos privados ${ }^{60}$, absolutos ${ }^{61}$ y extrapatrimoniales.

\section{EXTRAPATRIMONIALIDAD DE LOS DERECHOS DE LA PERSONALIDAD}

Esencial en la teoría de los derechos de la personalidad ha resultado la defensa de su cualidad extrapatrimonial. Guzmán señala que el hecho de ser persona es el título que hace sinónimas las expresiones derechos humanos, de la personalidad y extrapatrimoniales; sin embargo, "derechos extrapatrimoniales" sería la terminología comprensiva de todas las anteriores, y la recomendada, pues resalta la característica más notable de estos derechos: carecer de contenido pecuniario ${ }^{62}$. Se trata esta de la tesis dominante en la literatura chilena y que ha empujado a definir el derecho a la imagen como extrapatrimonial ${ }^{63}$.

Descubrir las cualidades de patrimonialidad y traficabilidad en este derecho (en cuanto personalísimo) aparece como una empresa a priori inviable. ¿Es el derecho a la imagen un bien en el contexto del Código Civil chileno?, si atendemos a la teoría de Guzmán la respuesta es negativa, pues los "[d]erechos de la persona (...) son extrapatrimoniales e incomerciables a la vez" ${ }^{64}$. El mismo autor sentencia que la expresión extrapatrimoniales "[s]ignifica desde luego lo que literalmente expresa, es decir, que los derechos en examen están fuera del patrimonio. Se quiere significar además que los mismos son ajenos al comercio y a la circulación. Finalmente, que no se pueden avalar en dinero. En suma, que no son bienes" ${ }^{65}$. En síntesis, reconocerles patrimonialidad, traficabilidad o comerciabilidad ${ }^{66}$ a los derechos personalísimos significaría autorizar a las personas para enajenar parte de su perso-

58 Es decir, que para reclamar su protección no se precisa de una concesión o reconocimiento especial por parte del ordenamiento jurídico, FueYo (1990) p. 32; Corral (1996) p. 87.

59 Es decir, ningún ser humano puede ser excluido de su goce y ejercicio. Sobre el derecho a la imagen DomínGUEZ y Domínguez (1968) p. 50.

60 Epígrafe VIII.

61 Nuestra doctrina enseña que los derechos de la personalidad son absolutos, pues lo que los caracterizaría es la existencia de un sujeto pasivo universal obligado a un deber general y negativo de abstención, tal como ocurre con los derechos reales, FueYo (1990) p. 17; Figueroa (1998) p. 24; Corral (2000) p. 355; FernándeZ Pérez (2004) p. 9; Lyon (2007) p. 80; Alessandri (2010) Tomo I, pp. 316 y 486. En contra, se ha manifestado Guzmán, para quien los derechos de la personalidad corresponden a derechos personales y, por tanto, son relativos, GuZMán (2006) pp. 86-87.

62 Según Guzmán, el Derecho romano reconocía como cosa incorporal, únicamente, a los derechos de contenido pecuniario, GuZMán (2006) pp. 55-56.

63 Según Vidal, es "solo cosa de revisar cada una de las características comunes a los derechos de la personalidad para observar que el derecho a la propia imagen no solo reúne tales cualidades, sino que sin temor a equivocarnos, puede ser el más característico de los derechos de la personalidad", VIDAL (2006) p. 536. Sobre la extrapatrimonialidad del derecho a la imagen (y desde diferentes perspectivas), Domínguez y Domínguez (1968) p. 33; Domínguez (1996) pp. 132-133; Peña (2002) p. 301; Bordalí (2006) pp. 215-216.

64 GuzMán (2006) pp. 56 y 150. A propósito de la "propietarización" de los derechos de las personalidad, Domínguez critica dicha analogía, entre otras cosas, porque estos no son disponibles, característica esencial del derecho de propiedad, Domínguez (1996) p. 129.

65 GuZmán (2006) p. 150. Cifuentes (1995) pp. 183, 184 y 229. Pero no olvidemos que el fin de la esclavitud es reciente. Quizás eso explique la aversión a patrimonializar aspectos vinculados a la persona, RoGEL (2007) pp. 261-262.

66 STITChKin (1961) p. 28. 
nalidad, subordinando su propio ser a la voluntad de un tercero ${ }^{67}$. De ahí que el estado actual, en nuestra doctrina y jurisprudencia, sea definir como extrapatrimoniales y excluir del tráfico jurídico a los derechos de la personalidad, ya que su marcada naturaleza espiritual y moral impediría reconocerles una inmediata utilidad económica o avaluarlos en dinero ${ }^{68}$.

Las consecuencias de considerar a los derechos personalísimos como extrapatrimoniales son evidentes:

i) son imprescriptibles ${ }^{69}$;

ii) son inembargables. Tratándose del derecho a la imagen podríamos cuestionar esto $^{70}$, pero, en verdad, resulta inoficioso ${ }^{71}$ porque embargar este no representaría ventaja pecuniaria alguna para el acreedor; quizás en el caso de personas famosas y solo para efectos de publicidad comercial, mas no se concibe retratar ilimitadamente a alguien (y a entera discreción del acreedor) sin que se atente, al mismo tiempo, contra la dignidad de la persona ${ }^{72}$;

iii) son intransmisibles ${ }^{73}$. Según Peña la intransmisibilidad del derecho a la imagen "importa la idea de que este, al igual que los otros derechos de la personalidad, no son susceptibles de transmitirse a los herederos del difunto, pues, por no forman parte del patrimonio, no se pueden trasmitir hereditariamente con él”, cuestión ratificada (a su juicio) por la doctrina chilena y española ${ }^{74}$. Sin embargo, en contra de esta intransmisiblidad podemos argumentar con la letra c) del art. 20 de la ley 19.039 cuando señala: "[N]o podrán registrarse como marcas el retrato de una persona natural cualquiera, salvo consentimiento dado por ella o por sus herederos, si hubiera fallecido", norma que aparta el derecho a la imagen de la categoría de los derechos de la personalidad, en este aspecto $^{75}$.

\footnotetext{
${ }_{67}$ La confusión en este tema lleva a efectuar declaraciones del tipo: "[C]reemos, por lo tanto, que puede existir una 'patrimonialización' de la persona, toda vez que su imagen tenga un valor comercial, lo que no se traduce en que pueda enajenar su imagen ya que esta es inseparable de su propia persona”, FERnÁndez (2004) p. 26.

68 En nuestra doctrina, se han pronunciado por esta tesis FueYo (1990) p. 17; FigueroA (1998) pp. 24-25; LyOn (2007) p. 80; Alessandri (2010) Tomo I, pp. 326 y 486. Corral ha llegado a sostener que debieran considerarse nulos e inejecutables aquellos contratos sobre "reality show" y los contratos sobre exposiciones pornográficas u obscenas, en Corral (2001) pp. 168 y 172-173.

69 Por todos, Alessandri (2010) Tomo I, p. 486. En el mismo sentido se pronuncia Lyon, aunque reconociendo excepciones como el "derecho moral del autor", LYON (2007) p. 80.

70 En efecto, no existe una ley especial que prohíba embargar el derecho a la propia imagen, como exige el art. $445 \mathrm{~N}^{\circ} 18$ CPC. Tampoco su ejercicio es "enteramente personal" como exige el art. $1618 \mathrm{~N}^{\circ} 9$ CC. en concordancia con el art. $445 \mathrm{~N}^{\circ} 15$ del CPC.

71 Cifuentes (1995) p. 187.

72 PEÑA (2001) pp. 298-299.

73 Alessandri (2010) Tomo I, pp. 316-317; Fueyo (1990) pp. 17 y 32.

74 Peña (2001) p. 299; El mismo (2002) p. 286.

75 Hirmas (1998) p. 10. Por lo demás, es posible y lícito que alguna persona posea un crédito mediante el cual pueda exigirle a otra determinados retratos. Piénsese en un fotógrafo publicitario que suscribió un contrato con determinada modelo o celebridad para realizar una serie de retratos. Fallecido el fotógrafo, dicho crédito podrá transmitirse a sus herederos o legatarios (aunque sin perjuicio de la, eventual, calificación intuitu personae del contrato).
} 
iv) son irrenunciables. Sabido es que la abdicación a nuestro honor o a la vida provoca natural aversión; de ahí que temas como el suicidio, la eutanasia e, incluso, el aborto sean, intensamente, rechazados en la doctrina chilena. Y no solo por cuestiones valóricas, sino también jurídicas, pues como dice Guzmán por el solo hecho ser personas tenemos derechos de la personalidad "y es jurídicamente imposible [en la actualidad] que no los tengamos" ${ }^{\text {" }}$. Sin embargo, en nuestro medio, varios autores se han abierto a la posibilidad de renuncia de algunos derechos de la personalidad "siempre y cuando ella tenga una causa legítima”77. Desde nuestra perspectiva, tratándose del derecho a la imagen (y atendiendo a su especial naturaleza) es posible justificar no solo la renuncia a la protección que el ordenamiento jurídico chileno le brinda (la prohibición de retratar personas sin su autorización) sino, explicar hasta su ejercicio y comerciabilidad.

\section{Patrimonialidad y tRAFicabilidad DEL DERECHO A LA PROPIA IMAGEN}

Es, precisamente, la extrapatrimonialidad de los derechos personalísimos la que ha terminado por reducir la protección de nuestra imagen a un mero derecho personal en cuya virtud podemos impedir que terceros nos retraten ${ }^{78}$. Sin embargo, la sola posibilidad de autorretararnos nos permite ya elucubrar sobre la renuncia, disposición o ejercicio del derecho a la imagen. Con mayor razón la autorización (expresa o tácita) que podemos otorgar para que otros nos retraten, incluso, mediando un contrato oneroso cuyo objeto sea crear, reproducir, publicar o comunicar públicamente un retrato. En nuestra opinión, la aceptación de la patrimonialidad y traficabilidad de este derecho permitirá, recién, concebirlo autónomamente y deslindarlo de otros, aun cuando ello signifique excluirlo de la categoría de los derechos de la personalidad.

No es de extrañar, que desde mediados del s. XX nuestra doctrina haya esbozado críticas respecto a los límites entre lo patrimonial y extrapatrimonial, tratándose de los derechos personalísimos. Stitchkin, por ejemplo, cuestionaba que el patrimonio fuera considerado como un atributo de la personalidad limitado, únicamente, a los derechos susceptibles de estimación pecuniaria ya que aquellas personas que no poseyeran ningún derecho de contenido pecuniario carecerían, entonces, de aquel ${ }^{79}$. En esta misma línea, los profesores Domínguez propusieron distinguir de los extrapatrimoniales aquellos derechos de la personalidad que presentaban "vocación patrimonial" como, por ejemplo, la libertad de comercio y los derechos patrimoniales de autor ${ }^{80}$. Varias décadas después, dicha incomodidad sigue presente en la doctrina la que con el afán dogmático de conservar el carácter extrapatrimonial de los derechos personalísimos ha morigerado su postura y tolerado cierta

\footnotetext{
76 GUZMÁN (2006) p. 150.

77 Lyon (2007) p. 80. Domínguez y Domínguez (1968) p. 49.

78 Nuestra doctrina ha reivindicado (casi, sin excepción) solo esta faceta "moral" o extrapatrimonial de los derechos personalísimos, FueYo (1990) pp. 69, 77 y 95; Figueroa (1998) p. 24; Alessandri (2010) Tomo I, p. 486.

79 STITCHKIN (1961) pp. 11, 13 y 19.

80 Domínguez y Domínguez (1968) pp. 34-35.
} 
traficabilidad de los mismos, particularmente, en aquellos casos en que el derecho en cuestión no tiene trascendencia social sino meramente individual, como ocurriría con ciertos aspectos vinculados a la privacidad y, por supuesto, el derecho a la imagen ${ }^{81}$. De esta manera, se ha ido consolidando una tendencia doctrinaria y jurisprudencial "relativista" que le reconoce a este último dos aspectos: a) uno negativo, moral o extrapatrimonial (amparado constitucionalmente) y b) una faceta positiva, comercial y patrimonial (aunque solo protegida infraconstitucionalmente) ${ }^{82}$.

Sin embargo, pese a que nuestra dogmática ofrece hoy el derecho a la imagen como "bipolar" 83 , comprensivo de aspectos económicos y comerciales, este sigue anclado en la categoría de los derechos extrapatrimoniales lo cual impide un estudio sistematizado del fenómeno del retrato de personas en Chile. En nuestra opinión, dicha concepción "bifronte" del derecho a la imagen se explica mejor por la armonización de las diferentes normas contenidas en nuestro ordenamiento jurídico que mandan ${ }^{84}$, prohíben ${ }^{85}$ o permiten retratar personas, incluido, el comercio de imágenes ${ }^{86}$ tal como ocurre en materia laboral ${ }^{87}$, en el

81 Aunque con recurso a eufemismos del tipo "interés patrimonial” o "interés de explotar comercialmente" el derecho a la imagen, Corral (2001) p. 172. Peña ha llegado a calificar el derecho a la imagen "objeto comercial", aunque luego pareciera contradecirse cuando señala que los "bienes de la personalidad (...) carecen de precio de mercado", Peña (2004) pp. 92-94. Sobre el mismo tópico, Hirmas (1998) p. 16; Barros (2006) p. 564. En Argentina, Cifuentes denomina a esta posibilidad como “influjo pecuniario", CifuENTES (1995) pp. 184-186.

82 Nogueira (siguiendo a la doctrina española) califica el derecho a la imagen como "bifronte", sin perjuicio que su dimensión patrimonial no forme parte del derecho fundamental, es decir, no reviste carácter constitucional, Nogueira (2007) p. 275.

83 Según Fernández, el derecho a la imagen se dividiría en un derecho de la personalidad (facultad de exclusión erga omnes) y un derecho patrimonial (facultad de aprovechamiento), aunque este último solo reivindicable por personas famosas, FERnÁNDEZ (2004) pp. 7-10. En el mismo sentido se han pronunciado también DomínGUEZ (1991) p. 95; Hirmas (1998) pp. 7 y 9; Barros (2006) pp. 543 y 564.

84 El D.L. N ${ }^{\circ} 102$ de 1924 (destinado a completar las disposiciones del D.L. N 26, también de 1924, y que estableció el Servicio de Identificacion obligatoria), estableció, por primera vez en Chile, la exigencia de incluir una fotografía en el prontuario y la cédula de identidad, tal como lo indican los incs. II y III de su art. $3^{\circ}$.

85 Tratándose de los menores, si bien existe particular prohibición para retratarlos y difundir su identidad, pareciera que la protección se les brinda en atención a la normativa específica sobre los derechos del niño (y sus respectivos principios como el "interés superior del niño", "libre desarrollo de su sexualidad", etcétera) más que por el derecho a la propia imagen. Así, por ejemplo, en el art. 33 de la ley 19.733 de 2001 o en los delitos contemplados en los arts. 366 quinquies, 374 bis y 374 ter del Código Penal (sobre producción, comercialización y tenencia de material pornográfico) en concordancia con el artículo 30 de la ley 19.846 de 2003. Sobre la exposición de retratos de menores en la televisión chilena, MAURÁS, MARTA (2013) pp. 1-24. Sobre la representación legal de los menores, en estos casos Corral (2001) p. 170.

86 Por ejemplo, el Servicio de Impuestos Internos, en oficio $N^{\circ} 4.842$, del 28 de octubre de 2004, declaró que: "la remuneración obtenida por un jugador de fútbol por su participación en un spot publicitario y sesión de fotos, efectivamente corresponde a un ingreso que se clasifica en el número $2^{\circ}$ del artículo $42^{\circ}$ de la Ley sobre Impuesto a la Renta, pues proviene del ejercicio de una ocupación lucrativa, debiendo emitir dicha persona la correspondiente boleta de honorarios de acuerdo a las formalidades que deben cumplir estos documentos"; además "[e]l uso en avisos publicitarios del nombre, imagen y figura personal de un deportista puede configurar el hecho gravado con el Impuesto al Valor Agregado establecido en el artículo $8^{\circ}$, letra h), del Decreto LEY $\mathrm{N}^{\circ}$ 825 , de 1974, que se refiere a cualquier forma de cesión del uso o goce temporal de marcas, patentes de invención, procedimientos o fórmulas industriales y otras prestaciones similares”, en concordancia con el art. 20 letra c) de la LEY 19.039 de 1991. El texto del oficio está disponible en: http://www.sii.cl/pagina/jurisprudencia/ adminis/2004/renta/ja834.htm. Fecha de la consulta: 12 de julio de 2015.

87 Reconociendo el fenómeno de la traficabilidad del derecho a la propia imagen y su desrregulación en el ámbito laboral chileno, Fernández (2004) p. 3. 
Derecho de autor ${ }^{88}$ y, por su puesto, en el Código Civil ${ }^{89}$. Es este universo de normas el que permite construir un régimen que regule ya no un derecho subjetivo, sino la libertad para retratar personas y explicar, plenamente, la renuncia, ejercicio, traficabilidad y comerciabilidad del derecho a la imagen en Chile ${ }^{90}$.

Entonces, ¿vale la pena seguir considerando el derecho a la propia imagen como un derecho personalísimo (y extrapatrimonial), o, más bien, debemos reivindicarlo derechamente como una categoría jurídica sui generis ${ }^{91}$ ? Y es que este no se traduce, únicamente, en una obligación de no hacer ${ }^{92}$. Concebido como libertad, se explica por qué cada persona puede autodeterminarse respecto a los retratos, desde autorretratarse hasta trabajar como modelo. Son, precisamente, estas conductas las que tolera y regula nuestro Derecho priva$\mathrm{do}^{93}$ :

i) Por aplicación del principio quae non sunt permissa probibita intelliguntur.

ii) A partir del art. 12 CC., podríamos sostener (en principio) que la renuncia al derecho a la imagen no está prohibida, desde que solo miraría al interés individual del renunciante. Serviría para justificar aquellos casos en que la persona tolera la captación o difusión no autorizada de un retrato suyo. Incluso, justificaría la conducta del tercero que nos retrata a expresa solicitud nuestra, desde que no existiría un interés público comprometido, a diferencia del que, por ejemplo, presta auxilio a otra persona para que se quite la vida ${ }^{94}$. Sin embargo, más que renuncia al derecho a la imagen lo que existe es un ejercicio de la libertad de retrato. $Y$ es que con este derecho no ocurre lo mismo que con los personalísimos (particularmente, el derecho a la vida) pues que una persona tolere que un tercero lo retrate (una o muchas veces) no le impide seguir autorretratándose o autorizar a otros para que lo hagan ${ }^{95}$. Podría hablarse de renuncia cada vez que la persona decide no ejercer las acciones respectivas para evitar la captación o impedir la difusión no autorizada de sus retratos $^{96}$. En los demás casos, es la misma persona que, en ejercicio de su li-

88 En especial, los arts. 24 y 34 de la LEY 17.336.

89 Arts. 1466 y 2006 y ss. del CC.

90 Incluyendo cuestiones sobre responsabilidad civil por la mayor o menor difusión de los retratos, CORRAL (1996) p. 94.

91 Antecedentes de esta discusión en el Derecho comparado, CifuEntes (1995) p. 507.

92 O de hacer, pero jamás de dar, según GuZmán (2006) pp. 85-86. Dice Hirmas, que esta concepción (de que los derechos de la personalidad consistirían en una obligación negativa que determina a la generalidad de las personas) ya estaba presente en la doctrina española e italiana de mediados del s. XX, Hirmas (1998) p. 7.

93 Y se proyectaría constitucionalmente, por lo demás.

$94 \mathrm{El}$ art. 393 del CP. prescribe: "El que con conocimiento de causa prestare auxilio a otro para que se suicide, sufrirá la pena de (...) si se efectúa la muerte”.

95 Es más, en virtud de un contrato de exclusividad la persona puede obligarse a no dejarse retratar y/o que sus retratos no sean aprovechados comercialmente por terceros ajenos a la relación contractual. Es lo que ocurre mutatis mutandi con la cesión de los derechos de autor regulada en LA LEY 17.336. Por lo demás, la especial naturaleza del derecho a la imagen determina que dicha renuncia o autorización solo sea temporal, pues de lo contrario se atentaría contra la dignidad de persona, BARros (2006) p. 564; Corral (2001) p. 163.

96 Para Nogueira "[e]l consentimiento consiste en una renuncia a la calificación del acto ajeno como constitutivo de intromisión ilegítima en ese caso concreto, constituyendo una autorización cuyo efecto es la supresión 
bertad y autonomía de la voluntad, consiente en ser retratada y decide los usos que permitirá de ello ${ }^{97}$. Así lo reconoce nuestro Derecho positivo en diferentes normas como, por ejemplo, el inc. II del art. 33 de la ley 19.733 cuando dice: "esta prohibición [la de divulgar la identidad o cualquier otro antecedente que conduzca a ella] regirá también respecto de las víctimas de alguno de los delitos contemplados en (...), a menos que consientan expresamente en la divulgación"; misma razón encontramos en el art. 20 letra c) de la ley 19.039 que prohíbe registrar como marca comercial el retrato de una persona "salvo consentimiento dado por ella o por sus herederos, si hubiera fallecido"; lo mismo ocurre con el inc. I del art. 161-A del Código Penal: "se castigará con la pena de (...) al que, en recintos particulares o lugares que no sean de libre acceso al público, sin autorización del afectado y por cualquier medio (...)"98.

Discusión aparte es la que versa sobre la presunción del consentimiento en lugares públicos o de libre acceso. Ella se genera a partir de la tesis que postula al derecho a la imagen como una faceta más de la vida privada de la persona y cuyo análisis postergamos para otra oportunidad ${ }^{99}$.

iii) Por último, prueba de que el derecho a la imagen no forma parte de la categoría de los extrapatrimoniales son las diversas normas contenidas en nuestra legislación que le reconocen expresamente traficabilidad y patrimonialidad. En Chile, la libertad de retrato presenta una estructura similar a la libertad de trabajo en el sentido que nadie puede ser obligado a retratarse contra o sin su voluntad, la persona puede autorretratarse o convenir con un tercero para que la retrate e, incluso, puede dejarse retratar y ser remunerado por ello, como ocurre con las modelos y celebridades ${ }^{100}$. La predicada extrapatrimonialidad del derecho a la imagen encuentra su "talón de Aquiles", precisamente, en el incesante tráfico y comercio de retratos. Y si bien en nuestro país hay quienes critican estas prácticas ${ }^{101}$, lo cierto es que "socialmente no se encuentra generalizada la idea de que comerciar con la intimidad o la propia imagen, por ejem-

de la ilicitud como causal de exclusión de antijuridicidad", Noguerra (2007) p. 270. Aunque, luego dirá también que "es necesario precisar que cuando se consciente en el uso de la imagen se está ejerciendo el derecho a la propia imagen en su sentido positivo, no existiendo así renuncia al ejercicio del derecho a la propia imagen”. El mismo (2007) p. 272. Para Barros el "aspecto positivo" del derecho a la imagen (su comerciabilidad o patrimonialidad) significa, precisamente, una renuncia a la privacidad que dicha prerrogativa conlleva, BARROS (2006) pp. 564 y 565, nota a pie de página no 94.

97 Peña (2002) p. 294; FernÁNdeZ (2004) p. 7.

98 Un redacción similar al art. 161-A del CP existía en el inc. II del art. 22 de la LeY 16.643 de 1967 (tras la modificación de la LEY 19.048 de 1991) que castigaba la captación de imágenes, en contextos privados, si con ello se afectaba la honra de la persona, salvo que el retratado lo hubiese autorizado.

99 Sobre esta presunción de consentimiento en lugares públicos, Domínguez y Domínguez (1968) pp. 32-33 y 46-49; Hirmas (1998) pp. 18-19; Corral (2000) p. 351, el mismo (2001) p. 162.

100 Para Guzmán la libertad de trabajo también opera en el Derecho privado, como ocurre con el contrato de arrendamiento de servicios, GUZMÁN (2001) pp. 250-251. En nuestra opinión, esta misma estructura (propia del Derecho privado) es la que se proyectaría en la Constitución, abarcando los aspectos "patrimoniales" y "no patrimoniales" del derecho a la imagen.

101 Corral (2001) pp. 172-173. 
plo, atente contra el orden público" ${ }^{102}$, salvo los retratos de corte pornográfico o aquellos donde figuran menores de edad. En nuestro medio, por ejemplo, se ha propuesto a la libertad para desarrollar cualquier actividad económica como una de las fuentes constitucionales del derecho a la imagen ${ }^{103}$ tesis que ha encontrado acogida en nuestra jurisprudencia, como en el año 2009 donde la C.A. de Santiago, conociendo de un recurso de protección, abordó diversos aspectos de este derecho (como que la "dimensión patrimonial" solo cuenta con protección legal, además de las cuestiones de propiedad intelectual involucradas), aunque lo más trascendente fue el reconocimiento que la Corte hizo del art. 19 No 21 CPR. En la parte pertinente de su fallo dijo que la faceta patrimonial "se enmarca en la explotación comercial de la imagen y aunque digna de protección, lo es por otros medios y se encuentra comprendida como una modalidad más dentro del derecho a ejercer toda actividad comercial lícita" ${ }^{104}$. En otras palabras, lo que hizo la Corte en este caso fue negar amparo vía recurso de protección, pero dejó abierta la posibilidad de reclamar por "otros medios" fundado en el derecho a ejercer toda actividad comercial lícita del art. 19 No 21 CPR.

Además de lo anterior, debemos señalar que dentro del sistema legal que regula el tráfico de "derechos de imagen" encontramos el art. 1466 CC. en cuanto permite la venta de retratos personales. Dice esta norma: "Hay asimismo objeto ilícito en las deudas contraídas en juego de azar, en la venta de libros cuya circulación es prohibida por autoridad competente, de láminas, pinturas y estatuas obscenas, y de impresos condenados como abusivos de la libertad de la prensa; y generalmente en todo contrato prohibido por las leyes". Interpretado a contrario sensu nos dice que "hay asimismo objeto lícito (...) en la venta de (...) láminas, pinturas y estatuas que no sean obscenas, y de impresos no condenados como abusivos de la libertad de la prensa”, hipótesis donde caben, evidentemente, los retratos. Luego, si dicha norma permite vender retratos, previa y necesariamente, implica que nuestro ordenamiento jurídico autoriza la mera creación o confección de ellos. Es decir, si tolera la venta de estos a maiori ad minus se ha de permitir (en ejercicio de nuestra libertad) el autorretrato o la simple confección de dichas obras efectuadas por un tercero gratuita u onerosamente. De hecho, el mismo Código Civil en sus arts. 2006 y siguientes regula el "arrendamiento de servicios inmateriales" donde cabe el oficio del retratista, labor que desde fines del s. XIX ha sido considerada lícita por nuestra jurisprudencia, no obstante que la calificación jurídica de las convenciones operadas con ocasión de dicho oficio haya variado desde la com-

\footnotetext{
102 Lasarte (1993) Tomo I, p. 223. Sobre el concepto de "orden público" en Chile, Cea (2012) Tomo II, pp. 503 y ss.

103 Anguita (2006) p. 379. Sobre el derecho a desarrollar actividades económicas y empresariales, GuZMÁN (2001) pp. 253 y ss.; CeA (2012) Tomo II, pp. 525 y ss.

104 CAROCA CON ELECTRONICA SUdAmERICANa (2009) Co 9.
} 
praventa hasta un contrato innominado ${ }^{105}$. En concordancia con estas últimas normas está la ley 17.336 que en diversos artículos autoriza a los retratistas para comerciar sus imágenes, como el art. 34 en cuanto dispone: "Corresponde al fotógrafo el derecho exclusivo de reproducir, exponer, publicar y vender sus fotografías, a excepción de las realizadas en virtud de un contrato, caso en el cual dicho derecho corresponde al que ha encargado la obra, y sin perjuicio de lo que establece el $\mathrm{N}^{\circ}$ 1) de la letra c) del artículo 24. La cesión del negativo o del medio análogo de reducción de la fotografía, implica la cesión del derecho exclusivo reconocido en este artículo" ${ }^{106}$. Por último, debemos invocar el Código del Trabajo que literalmente autoriza la traficabilidad y patrimonialidad del derecho a la imagen, por ejemplo, en su artículo 145-I: "El uso y explotación comercial de la imagen de los trabajadores de artes y espectáculos, para fines distintos al objeto principal de la prestación de servicios, por parte de sus empleadores, requerirá de su autorización expresa (...)”107.

\section{VII. ¿DERECHO FUNDAMENTAL A LA PROPIA IMAGEN?}

Coincidentemente con la evolución descrita para el derecho comparado ${ }^{108}$, en Chile el derecho a la imagen se positivó a propósito de la regulación de la propiedad intelectual. Luego sería estudiado como un derecho personalísimo ${ }^{109}$, para hoy ser considerado como un derecho fundamental implícito ${ }^{110}$.

Se ha dicho que cuando los derechos de la personalidad se enfrentaron al Estado, bajo un pretexto sociopolítico, adquirieron connotación pública abandonando necesariamente el ámbito de los Códigos Civiles desde que estos resultaron anacrónicos para asumir la complejidad de la protección jurídica de la personalidad, en relación a la trascendencia política otorgada por el Derecho público e internacional público ${ }^{111}$. Este último favoreció, incluso, la internacionalización de los derechos de la persona, consiguiendo influir en muchos ordenamientos internos tras el fin de la II Guerra Mundial ${ }^{112}$. La misma expresión "derechos humanos" se generalizó a propósito de este proceso de internacionalización, época de esplendor en que se abandonó el "principio de la jurisdicción interna" pasando los de-

\footnotetext{
105 Alessandri (2010) Tomo I, p. 493.

106 Por lo demás, existen en la misma LEY 17.336 otras normas referidas al comercio de pinturas, esculturas, dibujos, bocetos y demás obras de artes plásticas, como los arts. 36 y 37. Asimismo, no debemos olvidar al art. 20 letra c) de la LEY 19.039, sobre propiedad industrial, que reconoce la posibilidad de explotar comercialmente nuestra imagen cuando impide el registro marcario del "[r] etrato de una persona natural cualquiera, salvo consentimiento dado por ella o por sus herederos, si hubiera fallecido".

107 Misma razón se repite en el art. 152 bis $\mathrm{F}$ tratándose de deportistas profesionales.

108 AzUrmendi (1998) pp. 97 y ss.

109 Vidal (2006) p. 531.

110 Nogueira (2007) pp. 260 y 262.

111 Cifuentes (1995) p. 223, 225 y 227. Corral (1996) p. 87; Hirmas (1998) p. 30; Barros (2006) p. 535, 539-540.

112 Aldunate (2008) pp. 34-35. Domínguez (1996) p. 119; Corral (2014) p. 4.
} 
rechos individuales a situarse en un plano supranacional ${ }^{113}$ y cuya máxima consagración fue la Declaración Universal de los DD.HH. (1948), la que si bien recoge derechos ya reconocidos constitucionalmente, introdujo otros nuevos como el derecho a la vida privada ${ }^{114}$. El derecho a la imagen no alcanzó este reconocimiento internacional, aunque ha sido considerado como derecho humano en varias legislaciones y Constituciones europeas ${ }^{115}$.

Usualmente, con la expresión derechos humanos se alude a "ciertos atributos, facultades o capacidades que son reconocidos a todos los individuos de la especie humana, y cuya consagración positiva y respecto efectivo se reclaman de todo sistema políticojurídico" ${ }^{116}$, sirviendo de pauta para evaluar la legitimidad del mismo sistema, aunque ubicándose en un plano más político que jurídico ${ }^{117}$. La expresión "derechos fundamentales", en cambio, sí correspondería a un concepto jurídico ${ }^{118}$. Según Cea derechos fundamentales son aquellos "[d]erechos, libertades, igualdades o inviolabilidades que, desde la concepción, fluyen de la dignidad humana y que son intrínsecos de la naturaleza singularísima del titular de esa dignidad. Tales atributos, facultades o derechos públicos subjetivos son, y deben ser siempre, reconocidos y protegidos por el ordenamiento jurídico, permitiendo al titular exigir su cumplimiento con los deberes correlativos" ${ }^{119}$. En base a un criterio formal, se comprendería bajo esta nomenclatura solo a "aquellos derechos de la persona que han recibido consagración positiva, en particular, a nivel constitucional” sin importar la entidad de los mismos, concepción mayormente difundida en la literatura ${ }^{120}$. Atendiendo a su esencialidad, en cambio, son fundamentales "aquellos derechos de los que es titular el hombre, no por graciosa concesión de las normas positivas, sino con anterioridad e independientemente de ellas y por el mero hecho de ser hombre", es decir, aquellos derechos destinados a la satisfacción de las necesidades inherentes a una vida digna ${ }^{121}$. Explicando lo anterior, Aldunate ha señalado que el aspecto formal de la "fundamentalidad" de un derecho dice relación con su constitucionalización y todas las consecuencias que conlleva un precepto de esta naturaleza (supremacía constitucional, quórum especiales de reforma constitucional y exigencias materiales del ejercicio de las competencias de los órganos públicos), en cambio, el aspecto material alude al carácter constitutivo del orden político que asumen ciertos derechos, se encuentren o no consagrados en el texto constitucional: si lo están, se apartan de los "meramente constitucionales" y pueden llegar a constituir límites implícitos al poder

\footnotetext{
113 Aldunate (2008) pp. 31-34; Cea (2000) p. 164.

114 SuÁrez (2000) p. 105.

115 Vidal (2006) p. 533. No obstante, tratándose del derecho a la propia imagen, hay quienes reconociendo su carácter de derecho personalísimo lo niegan como derecho humano, CifuENTES (1995) p. 225, en referencia a la doctrina de los hermanos Mazeaud.

116 Aldunate (2008) p. 46.

117 Aldunate (2008) pp. 46-47. Cifuentes (1995) p. 223 y ss; Rogel (2007) p. 273.

118 Con referencia a la dogmática española, Aldunate (2008) p. 47.

119 CEA (2012) Tomo II, p. 221.

120 Serían los “derechos humanos positivados", Aldunate (2008) p. 47; o "derechos constitucionales", NogUeIRA (2007) p. 251.

121 Aldunate agrega que otro criterio para definirlos atiende a su universalidad, por lo que un derecho será fundamental en la medida que pueda ser reivindicado por todos los individuos "sin atender a la naturaleza o importancia de los intereses protegidos bajo este concepto”, Aldunate (2008) pp. 47-48.
} 
constituyente derivado; si no lo están, justifican la denominada "cláusula abierta" de derechos fundamentales que alude a la apertura del sistema de fuentes para considerar, como parte del ordenamiento constitucional, derecho fundamentales aún no incorporados en el texto de la Constitución ${ }^{122}$.

En nuestro país, precisamente, frente al silencio de los Tratados Internacionales sobre DD.HH. ${ }^{123}$ y al de la Constitución vigente, el derecho a la imagen ha sido concebido como un derecho fundamental implícito ${ }^{124}$. Sin embargo, se trata de una tesis todavía pendiente por demostrar en Chile, ya que no obstante existir reconocimiento jurisprudencial al respecto, su construcción ha sido sumamente precaria y parece haberse arribado a dicha conclusión únicamente por el ejercicio del recurso de protección fundado en los numerales 4 y 24 del art. 19 CPR, es decir, sin consideración a una dogmática iusfundamental, ni tampoco habiéndose demostrado su "fundamentalidad material"125. En nuestra opinión, el ordenamiento jurídico chileno cuenta con suficientes antecedentes para reconstruir y justificar la fundamentalidad del derecho a la propia imagen, aunque entendido como libertad y no como un derecho subjetivo público.

\section{LOS DERECHOS DE LA PERSONA COMO DERECHOS SUBJETIVOS}

Para finalizar nuestra exposición, nos referiremos a otra cuestión que mantiene dividida a la doctrina chilena ${ }^{126}$ y que también ha influido (negativamente) en la construcción del derecho a la imagen. Se trata de la asignación del carácter de subjetivos a los derechos de la persona: "derechos subjetivos privados"127, en el caso de los personalísimos, y "derechos subjetivos públicos”, en el caso de los fundamentales ${ }^{128}$.

Tratándose de los derechos de la personalidad, un sector rechaza tal calificación desde que objeto y sujeto de derecho se confundirían ${ }^{129}$. Al respecto Domínguez ha señalado que la falta de renovación y adaptación de nuestro Código Civil ha llevado a que, por vía de la constitucionalización, toda cuestión se identifique como cosa corporal o incorporal y derecho real o personal, situación que no se aviene con los derechos de la personalidad que no son reales ni personales, ya que esta clasificación solo aplica para los derechos patrimoniales y esencialmente disponibles ${ }^{130}$. Sin embargo, para la mayoría de nuestra doctrina los

\footnotetext{
122 Pues como señala Aldunate, los derechos fundamentales no son solo "derechos de defensa" (función clásica o liberal) frente al poder estatal. En un sentido más profundo, su función primaria es política, pues forman parte del principio de legitimidad, constituyendo el poder, Aldunate (2008) p. 47-49 y 55. García-Huidobro 1998) pp. 14 y 15. Sobre la "cláusula abierta" de los derechos fundamentales, Nogueira (2007), pp. 253-255.

123 Azurmendi (1998) p. 99.

124 Por todos, Nogueira (2007).

125 Aldunate (2007) pp. 103 y ss.

126 Alessandri (2010) Tomo I, p. 485.

127 Cifuentes (1995) p. 200.

128 Cifuentes (1995) p. 223.

129 LYON (2007) p. 79.

130 Es más, agrega Domínguez, que aun considerando solo a los derechos patrimoniales la cuestión resulta inapropiada. Con apoyo en doctrina extranjera, Domínguez (1996) p. 130. Ejemplo de este vicio es la calificación
} 
personalísimos sí son derechos subjetivos privados, taxonomía predicable tanto respecto del derecho a la vida privada, a la honra y a la imagen ${ }^{131}$.

En cuanto a los derechos fundamentales, no obstante ser definidos por algunos como derechos públicos subjetivos ${ }^{132}$, se dice que no son meros derechos subjetivos como los que habitualmente tutela la jurisdicción común u ordinaria ${ }^{133}$. Aldunate, por ejemplo, ha dicho que el concepto derecho público subjetivo (propia de Jellineck) se agota en la relación individuo-Estado y, por lo demás, abarca cuestiones que no se condicen con la noción privada de derecho subjetivo como ocurre, por ejemplo, con aquellas simples certificaciones que efectúa alguna autoridad administrativa o ciertas prerrogativas como el derecho a la igualdad que, para estos efectos, es considerado Derecho objetivo ${ }^{134}$. Especial crítica ha realizado este autor a la tesis de Guzmán Brito por calificar a los derechos de la personalidad ${ }^{135}$ como personales (y, por tanto, subjetivos), ya que aun cuando estos y los fundamentales tengan en común el reconocimiento de ciertos poderes al individuo, dicho reconocimiento se realiza en condiciones radicalmente distintas en uno y otro caso. En efecto, para Aldunate mientras que el individuo puede en cualquier momento de su vida adquirir o desprenderse de derechos subjetivos privados, sin que se vea afectada su calidad de persona ni su dignidad, los derechos fundamentales corresponden a aquellos atributos que se le reconocen a cada individuo en el ordenamiento jurídico por el solo hecho de ser tal, concreciones de su dignidad; jurídicamente hablando, solo pueden ser afectados o lesionados, pero no se concibe una "pérdida" o "adquisición" de derechos fundamentales. Siendo así, agrega Aldunate, parece más conveniente mantener una separación entre el concepto de derecho subjetivo privado (nacido en el Derecho privado y ligado al ámbito patrimonial) y el de derecho subjetivo público nacido en un contexto distinto, el de los derechos del hombre como principios fundantes del Derecho público contemporáneo ${ }^{136}$. Sentencia este autor: "[h] asta donde alcanza mi limitado conocimiento en la materia, la doctrina del Derecho civil no ha pretendido ingresar la categoría de los derechos o atributos de la personalidad

que Domínguez Hidalgo hiciera del derecho a la imagen como un derecho real que recae sobre "la figura de la persona representada", Domínguez (1991) p. 95.

131 Por todos, GuZMán (2006) p. 85 y ss.

132 Cea (2012) Tomo II, p. 221. Anteriormente, el mismo (2000) p. 153. Sobre la cuestión de los derechos subjetivos en el origen de los derechos humanos, García-Huidobro (1998) pp. 15-16.

$133 \mathrm{Al}$ menos los conocidos vía recurso de protección, Gómez (2005) p. 21. Nuestra jurisprudencia, en más de alguna ocasión, ha calificado el derecho a la imagen como "derecho público subjetivo". Así por ejemplo, la C.A. de Copiapó, en Mendoza con Contralora Regional de AtaCAma (2008) señaló en su considerando sexto que "[e]l denominado derecho público subjetivo a la imagen consiste en la facultad de excluir a terceros del uso, apropiación o interferencia ilegítima de la apariencia o figura del individuo”.

134 Aldunate (2008) p. 54. Cifuentes (1995) p. 115, nota a pie de página no 8.

135 O "extrapatrimoniales" en la nomenclatura de GuZMÁn (2006) p. 55. Guzmán volverá a reiterar su postura luego, aunque pareciera contradecirse cuando señala que los derechos contenidos en la Constitución son derechos subjetivos privados (en relación con su contenido privatístico) como el derecho de propiedad, no así como la protección de la vida del que está por nacer o el art. 19 No 4 "[q]ue no formulan ningún derecho subjetivo, sino que establecen un paladino Derecho objetivo, aunque, al menos en el segundo caso, el intérprete puede verse tentado de transformar la actual dicción de la norma en otra que rezara: el derecho al respecto y protección (...)", el mismo (2001) p. 31-32.

136 Aldunate (2008) p. 57. 
(la más cercana conceptualmente a la de derechos fundamentales) dentro de la clasificación de los derechos reales y personales. La tesis de Guzmán no es sino indicativa del problema conceptual más profundo al que ha conducido el uso del nombre 'derechos subjetivos' en el campo de los derechos fundamentales, y que es su 'sustancialización' o 'cosificación': los derechos fundamentales, ingresando al discurso de los derechos subjetivos, empiezan a ser apreciados como 'bienes'. Estos bienes pasan a ser considerados luego verdaderos objetos en relación a su sujeto titular (como pueden ser los derechos reales y personales). Con esto se abandona una sana estructura conceptual en que los derechos fundamentales se aprecian en lo que son: fórmulas lingüísticas para aludir a dimensiones del propio sujeto jurídicamente tuteladas (y no facultades del individuo definidas en torno a objetos distintos a él)"137.

No se trata esta de una cuestión baladí. Sobre todo si pensamos que las cualidades que distancian el derecho a la imagen de los derechos de la personalidad son aquellas que más aversión causan entre los tratadistas: patrimonialidad, comerciabilidad y traficabilidad, típicas de los derechos subjetivos. Ahora bien, y pese a que la configuración de aquel no es la de un derecho subjetivo privado, nada impide que en su virtud (entendido como libertad) sea posible crear derechos personales u obligarse. Así por ejemplo, toda persona puede autorretratarse, pero además convenir con un tercero para que lo retrate (obligación de hacer) generalmente a cambio de una contrapestación en dinero (obligación de dar). Incluso, tratándose de modelos hombres o mujeres estos se obligan para con un tercero a dejarse retratar en determinadas condiciones (obligación de hacer) a cambio de una remuneración previamente acordada (obligación de dar), incluso pueden convenir exclusividad con su contratante y no dejarse retratar por otros (obligación de no hacer). Se tratan estas de actividades y contratos realizados en virtud del principio de la autonomía de la voluntad, no prohibidas por nuestra legislación y perfectamente fundadas en el libre desarrollo de la personalidad, la libertad de trabajo, de empresa y la libre circulación de bienes y servicios, todas reconocidas constitucionalmente en nuestra Carta Magna.

\section{CONCLUSIONES}

1.- El ordenamiento jurídico chileno limita la libertad general para captar imágenes de objetos y personas. En este último caso, dichos límites se corresponden con lo que clásicamente se denomina "derecho a la propia imagen".

2.- No toda imagen requiere de autorización previa del efigiado. Solo los retratos, es decir, aquella especie de imagen que permite identificar a la persona o aporta datos que facilitan su identificación.

3.- $\quad$ En Chile, el derecho a la imagen no es un derecho real de propiedad, pues su objeto no es una cosa corporal. Pero tampoco incorporal, sino inmaterial: "la libertad de retrato".

4.- La creación de retratos constituye el objeto principal del derecho a la propia imagen, situación donde confluye simultáneamente el estatuto relativo al

137 Aldunate (2008) p. 57, nota a pie de página no 97. 
Derecho de autor en virtud del "principio de protección automática de las obras".

5.- $\quad \mathrm{Al}$ igual que en el Derecho comparado, en nuestro país el análisis del derecho a la imagen comenzó a partir de la Propiedad Intelectual, para luego ser considerado como un derecho personalísimo y luego, hacia finales del siglo XX, como derecho fundamental.

6.- $\quad$ En el estado actual de la dogmática chilena, es posible deslindar las categorías "derechos de la personalidad" y "derechos fundamentales", correspondiéndose la primera con el Derecho civil y la segunda con el Derecho constitucional.

7.- Los derechos de la personalidad son, por antonomasia, extrapatrimoniales. Siendo así, el derecho a la propia imagen no corresponde a dicha categoría pues el propio Derecho positivo chileno le reconoce cualidades de patrimonialidad y traficabilidad.

8.- El derecho a la propia imagen puede ser reconstruido en nuestro ordenamiento jurídico y justificado como fundamental, pero ya no como un derecho subjetivo público, sino como la libertad para autodeterminarse respecto a los retratos.

\section{BIBLIOGRAFÍA CITADA}

Aldunate Lizana, Eduardo (2008): Derechos Fundamentales (Santiago, LegalPublishing).

Alessandri, Arturo y Somarriva, Manuel (2010): Tratado de Derecho Civil, Tomo I (Santiago, Editorial Jurídica de Chile).

Anguita Ramírez, Pedro (2006): "Jurisprudencia constitucional sobre el derecho a la propia imagen y la vida privada en Chile (1981-2004): un intento de sistematización” en GonzÁlez, Felipe (edit.), Libertad de Expresión en Chile (Santiago, Facultad de Derecho, Universidad Diego Portales) pp. 319-521.

Azurmendi Adarraga, Ana (1998): El derecho a la propia imagen: su identidad y aproximación al derecho a la información (México D.F., Universidad Iberoamericana).

Barros Bourie, Enrique (2006): Tratado de Responsabilidad Extracontractual (Santiago, Editorial Jurídica de Chile).

Bordalí Salamanca, Andrés (2006): "El recurso de protección entre exigencias de urgencia y seguridad jurídica”, Revista de Derecho Valdivia, vol. 19, No 2: pp. 205-228.

Cea EgaÑa, José Luis (1982): "Estatuto constitucional de la información y opinión", Revista de Derecho de la Pontificia Universidad Católica de Valparaíso, No 6: pp. 179-220.

Céa Egaña, José Luis (1996): "El derecho constitucional a la intimidad", Revista Gaceta Jurídica, No 194: pp. 27 y ss.

Cea Egaña, José Luis (2000): "Los derechos a la intimidad y a la honra en Chile", Revista Ius et Praxis, vol. 6, № 2: pp. 153-169.

Cea Egaña, José Luis (2012): Derecho Constitucional chileno, Tomo II (Santiago, Ediciones Universidad Católica de Chile, segunda edición actualizada).

Cifuentes, Santos (1995): Derechos personalísimos (Buenos Aires, Editorial Astrea, segunda edición actualizada y ampliada). 
Corral Talciani, Hernán (1996): "Derechos al honor, vida privada e imagen y responsabilidad civil por los daños provocados por empresas las periodísticas”, Revista de Derecho de la Universidad Católica de la Santísima Concepción, vol. 4, No 5: p3-96.

Corral Talciani, Hernán (2000): "Configuración jurídica del derecho a la privacidad II: concepto y delimitación”, Revista Chilena de Derecho, sección estudios, vol. 27, No 2: pp. 331-355.

Corral Talciani, Hernán (2001): "La vida privada y la propia imagen como objetos de disposición negocial", Revista de Derecho de la Universidad Católica del Norte, No 8: pp. 159-175.

Corral Talciani, Hernán (2006): "Sobre la responsabilidad civil de los periodistas y de los medios de comunicación social por atentados a la honra, intimidad e imagen", Información Pública, vol. 4, No 2: pp. 253-286.

Corral Talciani, Hernán (2014): “Constitucionalización del Derecho civil. Reflexiones el sistema jurídico chileno”, en Villabella Armengol, Carlos et al. (coord.), Derecho Civil constitucional (Puebla, Grupo Editorial Mariel S.C.) pp. 1-16.

Domínguez ÁGuila, Ramón (1996): "Aspectos de la constitucionalización del Derecho civil chileno", Revista de Derecho y Jurisprudencia, tomo 93, No 3: pp. 107-137.

Domínguez Águila, Ramón y Domínguez Benavente, Ramón (1968): "Las servidumbres a que obliga la grandeza. La esfera de intimidad y las personalidades públicas", Revista de Derecho de la Universidad de Concepción, No 144: pp. 28-52.

Domínguez Hidalgo, Ramón (1991): El derecho de la persona sobre su propia imagen (Concepción, Facultad de Derecho Universidad de Concepción, memoria de prueba para optar al grado de licenciado en Ciencias Jurídicas y Sociales).

Fernández Pérez, Francisca (2004): Regulación contractual del derecho de imagen del deportista profesional en Chile (Talca, Escuela de Derecho Universidad de Talca, memoria de prueba para optar al grado de licenciado en Ciencias Jurídicas y Sociales).

Figueroa Yáñez, Gonzalo (1998): "Los derechos de la personalidad en general: concepción tradicional", Revista de Derecho de la Universidad Católica de Valparaíso, No 19: pp. 2134.

Figueroa Yáñez, Gonzalo (2001): "El Derecho de la persona como rama autónoma del Derecho Civil", Revista Derecho y Humanidades, No 8: pp. 57-63.

Fueyo Laneri, Fernando (1990): Instituciones de Derecho Civil moderno (Santiago, Editorial Jurídica de Chile, primera edición).

García-Huidobro, Joaquín, Martínez, José, y Nuñez, Manuel (1998): Lecciones de Derechos Humanos (Valparaíso, EDEVAL, segunda edición).

Gómez Bernales, Gastón (2005): Derechos fundamentales y recurso de protección (Santiago, Ediciones Universidad Diego Portales).

GuZmán BRITo, Alejandro (1988): "La naturaleza de las garantías constitucionales de la persona examinada a través de su protección judicial”, Revista de Derecho y Jurisprudencia y Gaceta de los Tribunales, Tomo 85, No 2: pp. 105-112.

GuZMÁn BRITO, Alejandro (2001): El Derecho privado constitucional de Chile (Valparaíso, Ediciones Universitarias de Valparaíso). 
GUZMÁN BRITO, Alejandro (2006): Las cosas incorporales en la doctrina y en el derecho positivo (Santiago, Editorial Jurídica de Chile, segunda edición actualizada).

Hirmas Adams, Lorena (1998): Aspectos principales del derecho a la imagen en Chile y su limitación en otros paises (Viña del Mar, Facultad de Derecho Universidad Adolfo Ibáñez, memoria de prueba para optar al grado de licenciado en Ciencias Jurídicas y Sociales).

IgARTUa ARregui, Fernando (1991): La apropiación comercial de la imagen y del nombre ajenos (Madrid, Editorial Tecnos S.A.).

LARraín PÁEZ, Cristián (2012): "Jurisprudencia reciente en materia de responsabilidad civil por ejercicio no autorizado del derecho a la imagen. En particular, sobre el daño", en Domínguez Hidalgo, Carmen et al. (coord.), Estudios de Derecho civil VIII. Jornadas Nacionales de Derecho Civil, Santa Cruz 2012 (Santiago, LegalPublishing, Thomson Reuters) pp. 573-583.

Lasarte, Carlos (1993), Principios de Derecho civil, Tomo I (Madrid, Editorial Trivium, segunda edición).

López Santa María, Jorge (1982): "Consideraciones sobre el derecho a la privacidad o al secreto de la vida privada", Revista de Derecho y Jurisprudencia y Gaceta de los Tribunales, Tomo 79, No 3: pp. 65-78.

Lipszyc, Delia (1993): Derecho de autor y derechos conexos (Argentina, Ediciones UNESCO/ CERLALC/ZAVALIA).

Lyon Palma, Alberto (2007): Personas Naturales (Santiago, Ediciones Universidad Católica de Chile, tercera edición ampliada).

Maurás, Marta (2013): “Derechos del niño y medios de comunicación”. Disponible en: http://www.cntv.cl/prontus_cntv/site/artic/20130829/asocfile/20130829121455/derechos_del_nin_o_y_medios_de_comunicacio_n_1__copia.pdf. Fecha de consulta: 15 de agosto de 2015.

NeWell, BRYCE (2011): "Freedom of Panorama: a comparative look at international restrictions on public photography”, Creighton Law Review, 44, No 2: pp. 405-428.

Nogueira AlcalÁ, Humberto (2007): "El derecho a la propia imagen como derecho fundamental implícito. Fundamentación y caracterización”, Revista Ius et Praxis, año 13, No 2: pp. 245-285.

Novoa Monreal, Eduardo (1981): Derecho a la vida privada y libertad de información. Un conflicto de derechos (México D.F., Siglo XXI Editores S.A, segunda edición).

Peña Atero, José Ignacio (2001): "El derecho a la propia imagen en la doctrina y jurisprudencia chilenas", Revista de Derecho Público, vol. 63: pp. 279-306.

Peña Atero, José Ignacio (2002): "La protección del derecho a la propia imagen", Revista de Derecho Público, vol. 64: pp. 283-308.

Peña González, Carlos (1996): "El Derecho civil en su relación con el Derecho internacional de los Derechos Humanos", en Medina, Cecilia y Mera, Jorge (edit.), Sistema Jurídico y Derechos Humanos (Santiago, Universidad Diego Portales, Cuadernos de análisis jurídico, serie Publicaciones especiales, núm. 6) pp. 551-603.

Peña GonzÁlez, Carlos (2004): "Informe sobre el proyecto de ley de protección del honor y la intimidad de las personas", Temas de Responsabilidad Civil (Santiago, Universidad 
Diego Portales, Cuadernos de Análisis Jurídico, Colección de Derecho privado, Santiago, vol. I) pp. 75-104.

Pfeffer Urquiaga, Emilio (2000): "Los derechos a la intimidad o privacidad, a la honra y a la propia imagen. Su protección frente a la libertad de opinión e información”, Ius et Praxis, vol. 6, No 1: pp. 465-474.

Rogel Vide, Carlos (2007): "Origen y actualidad de los derechos de la personalidad", IUS: Revista del Instituto de Ciencias Jurídicas de Puebla A.C., No 20: pp. 260-282.

Rovira SueIro, María (2000): El derecho a la propia imagen. Especialidades de la responsabilidad civil en este ámbito (Granada, Editorial Comares).

Royo Jara, José (1987): La protección del derecho a la propia imagen (Madrid, Editorial Colex).

Soto Kloss, Eduardo (1993): "Comentario al fallo de la Corte de Santiago de 17 de noviembre de 1992", Revista de Derecho y Jurisprudencia, tomo 89, sec. 5: pp. 345-349.

Stitchkin Branover, David (1961): "Los bienes extrapatrimoniales", Revista de Derecho Universidad de Concepción, No 115: pp. 2-29.

SuÁrez Crothers, Christian (2000): "El concepto de derecho a la vida privada en el Derecho anglosajón y europeo", Revista de Derecho Valdivia, vol. 11: pp. 103-119.

Vergara Blanco, Alejandro (1992): "La propietarización de los derechos", Revista de Derecho de la Universidad Católica de Valparaíso, vol. 14: pp. 281-291

VIAL SOlar, Tomás (2000): "Hacia la construcción de un concepto constitucional del derecho a la vida privada", Revista Persona y Sociedad, vol. 14, No 3: pp. 47-68.

Vidal Beros, Christian (2006): "La protección del derecho a la propia imagen como derecho de la personalidad en un mundo globalizado", en XXXV Jornadas de Derecho Público. El Derecho Público chileno y la globalización, Tomo I (Valparaíso, Edeval) pp. 531-539.

ZúNiga URbina, Francisco (1997): "El derecho a la intimidad y sus paradigmas", Ius et Praxis, año 3, No 1: pp. 285-314.

\section{NORMAS CITADAS}

Código Civil (CC.)

Código Procesal Penal (CPP.)

Código de Procedimiento Civil (CPC.)

Código Penal (CP.)

LEY 16.643 (04/09/1967), sobre abusos de publicidad.

LEY No 17.336 (02/10/1970), Propiedad Intelectual.

LEY No 19.039 (25/01/1991), establece normas aplicables a los privilegios industriales y protección de los derechos de propiedad industrial.

LEY No 19.733 (04/06/2001), sobre libertades de opinión e información y ejercicio del periodismo.

LEY No 19.843 (04/01/2003), sobre calificación de la producción cinematográfica.

LeY No 20.564 (03/02/2012), establece ley marco de los Bomberos de Chile.

Decreto Ley N $\mathrm{N}^{\circ} 26(18 / 11 / 1924)$, establece el servicio de identificación personal obligatorio. 
Decreto Ley No $102(18 / 11 / 1924)$.

DeCReto Ley No 588 (03/11/1925), sobre organización de los servicios de la propiedad industrial.

Decreto Supremo Nº 64 (27/01/1960), reglamenta la eliminación de prontuarios penales, de anotaciones y el otorgamiento de certificados de antecedentes.

Decreto Supremo No 910 (15/09/1975), aprueba reglamento para el transporte y tránsito de personas en red de Metro.

Decreto $N^{\circ} 1976$ exento (24/12/2007), declara Monumento nacional en la categoría de Monumento histórico el Santuario Inmaculada Concepción de Corinto, ubicado en la comuna de Pencahue, provincia de Talca, VII Región del Maule.

RESOLUCIÓn Nº 861 exenta (02/09/2013), señala características y fija menciones de la cédula de identidad electrónica que emita el Servicio de Registro Civil e Identificación.

\section{JURISPRUDENCIA CITADA}

Caszely y otros con SAlo EDitores LtDa. (1982): Corte de Apelaciones de Santiago, 5 de julio de 1982 (recurso de protección), Revista Chilena de Derecho, vol. 9, No 2: pp. 368 y ss.

Bohme Bascuñán con Clínica Alemana de Santiago (1992): Corte de Apelaciones de Santiago, 17 de noviembre de 1992 (recurso de Protección), en Soto Kloss, Eduardo (1993): "Comentario al fallo de la Corte de Santiago de 17 de noviembre de 1992", Revista de Derecho y Jurisprudencia, tomo 89, sección 5: pp. 345-349.

Cohen Sabah con Diario la Tercera (2000): Corte de Apelaciones de Santiago, 26 de enero del 2000 (recurso de protección). Disponible en www.pjud.cl. Fecha de consulta: 16 de agosto de 2015.

Mendoza Morales y otros con Contraloría Regional de Atacama (2008): Corte de Apelaciones de Copiapó, 12 de junio de 2008 (recurso de protección). Disponible en: www. pjud.cl. Fecha de consulta: 15 de julio de 2015.

CAROCA RodRíguez CON ELECTRÓNICA SUdAMERICANA Limitada (2009): Corte de Apelaciones de Santiago, 24 de marzo de 2009 (recurso de protección). Disponible en: www.pjud.cl. Fecha de consulta: 15 de julio de 2015.

Caroca Rodríguez con Electrónica Sudamericana Limitada (2009): Corte Suprema, 9 de junio de 2009 (recurso de protección). Disponible en: www.pjud.cl. Fecha de consulta: 15 de julio de 2015.

CRUz Llancamil con Consejo de Defensa del Estado (2010): Corte Suprema, 30 de agosto de 2010 (recurso de protección). Disponible en: www.pjud.cl. Fecha de consulta: 16 de agosto de 2015.

Alvarado Granja con CANAL 13 S.A. (2014): Corte de Apelaciones de Valparaíso, 7 de julio de 2014 (recurso de protección). Disponible en: www.pjud.cl. Fecha de consulta: 16 de agosto de 2015. 
